\title{
Dialogue with Hou Ying: \\ A Dance Artist's Reflections on the Crisis of Human Civilization
}

\author{
对话侯莹 : 一个舞蹈艺术家对人类文明危机的思考
Aimee T. Liư ${ }^{1}$, Hou Ying ${ }^{2}$ and Amanda Liư
${ }^{1}$ Creative Arts in Education and Therapy, China
${ }^{2} \mathrm{Hou}$ Ying Dance Theater, China
${ }^{3}$ Wuhan Yi Ye Psychological Services Center, China

\begin{abstract}
In March 2019, Hou Ying presented a site-specific dance performance called "Immanent fall" as part of the "Civilization: The Way We Live Now" series to an audience in the labyrinth-like exhibition hall in the Center for Contemporary Art in Beijing. Her creation seems to have had an amazing predictive function which was almost identical to what is happening in the world today, the outbreak of COVID-19. In an in-depth interview with Hou Ying and Aimee T. Liu, Hou shared her inspiration for creating the work "Immanent Fall", and explored her reflections on the crisis that hit human civilization on 23 February, 2020.
\end{abstract}

Keywords: COVID-19, crisis, dance, Hou Ying, human civilization.

\section{摘要}

2019年3月，在北京尤伦斯当代艺术中心 ( UCCA ) 特别项目《文明 : 当代生活启示录》 迷宫般的展厅中，侯莹为观众呈现了一部特定场域的舞蹈作品《坠入内在》，作品中情 景与当下世界正在爆发的 2019 冠状病毒病疫情场景，简直如出一辙，她的创作似乎具有 一种神奇的预言功能。2020年2月23日，在CAET编辑刘婷对侯莹的采访中，她分享了自 己创作《隹入内在》的灵感源泉，并探讨了一个舞蹈艺术家对人类文明危机的思考。

关键词 : 2019冠状病毒病，危机，舞蹈，侯莹，人类文明

1. As a creator, the artist will maintain a kind of perception, awareness and thinking about many things that happen in the world.

Aimee: Hou Ying, thank you for taking some time off from your busy schedule to answer a few questions about your dance masterpieces. Could you tell us about yourself first?

Hou Ying: It's my pleasure. I'm the founder of Hou Ying Dance Theater. In 1996, I took my work Spirit of Night to the Russian International Dance Competition and won the Gold Prize for Creation. In 2001, I was awarded the Asian Cultural Council Scholarship to research and create in New York. In 2002, I joined the New York Shen Wei Dance 
Arts, later working as Rehearsal Director of the studio. In 2004, I was named "Year's Most Outstanding Dancer" by the New York Times. Then, I returned to China with Shen Wei and created "The Picture" (which last for eight minutes) for the 2008 Summer Olympics opening ceremony in Beijing. In 2011, I founded Hou Ying Dance Theater to promote the education and improvisation of Modern Dance in China. My dance focuses on exploring the inner heart, soul and spirit with body language.

Aimee: You have presented a site-specific dance performance called "Immanent Fall" (see Figure 1) to the audience in the labyrinth-like exhibition hall at Beijing's UCCA Center for Contemporary Art for the "Civilization: The Way We Live Now" in March 2019 (UCCA, 2019), your work was almost identical to what is happening in the world now. And your creation seemed to have an amazing predictive function. So, what was the inspiration that triggered you to create the masterpiece of "Immanent Fall" (Hou Ying Dance Theater, 2019)?

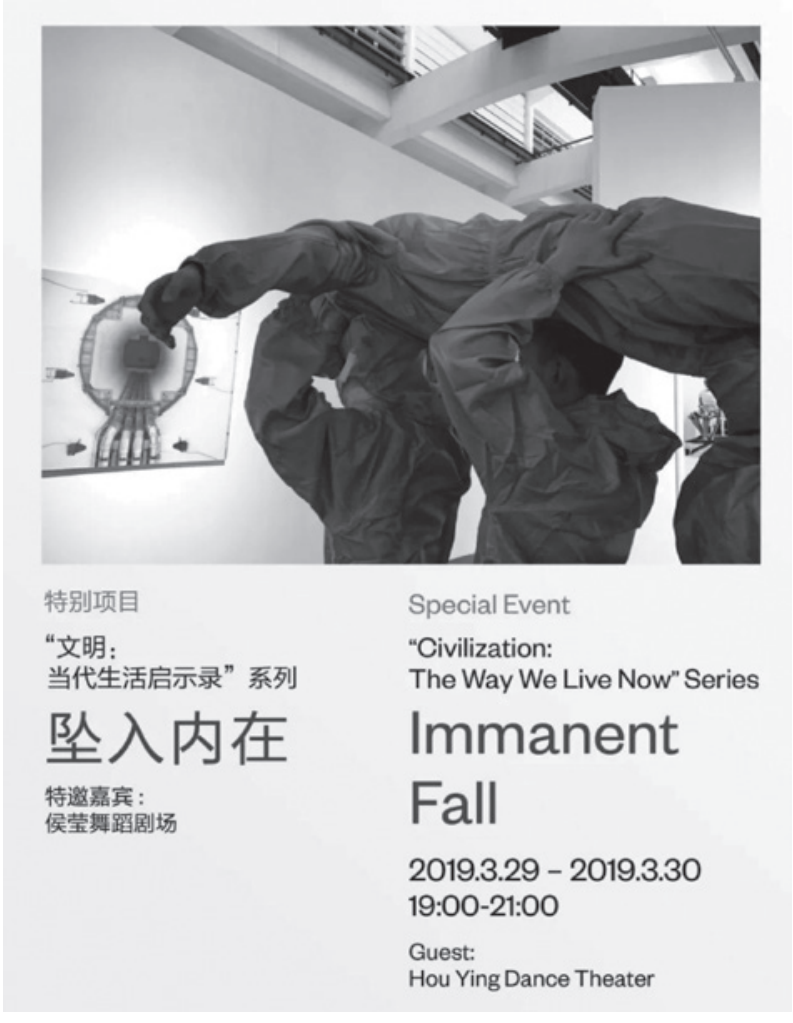

FIGURE 1 | Immanent Fall poster.

Hou Ying: If we want to talk about the artist's foresight, the artist's perception of life, of the world, and of human beings, we should trace back to the artists themselves first. As a creator, the artist will maintain a kind of perception, awareness and thinking about many things that happen in the world. With such forward-looking thinking ability, the 
artist is not only able to think about the past, but also to think about the future, and thus, can insinuate more things. In other words, in the process of creation, artists will associate or perceive a lot of things from the heart. Personally, I am more concerned about human intuition. As an artist, I will take time to observe my heart, feel the present inner state deeply, sincerely, truly and honestly, and return to my inner state pursuing my inner perception, and fully listening to my inner voice. It is my heart that leads me. In other words, my consciousness and perception go far beyond cognition. I believe that human cognition is limited, that it can be acquired through books and experience, and this so-called cognition and experience are all based in past facts. Therefore, only when you do not have a very clear and definite answer to what is happening right now, this subconscious and forward-looking sense of touch will then emerge.

As an artist, if you can let your subconsciousness emerge bravely and boldly, then you can be sensitive to things that ordinary people can't perceive. More often, artists' perceptions are unfounded, we have deep concern about the future of mankind and see things that are more harmful to humans than others see. Because we never put ourselves in a state of happiness, or deceive ourselves in daily life, what we see are problems that are not conducive to human life, and that are more likely to touch and grasp my heart (see Figure 2).

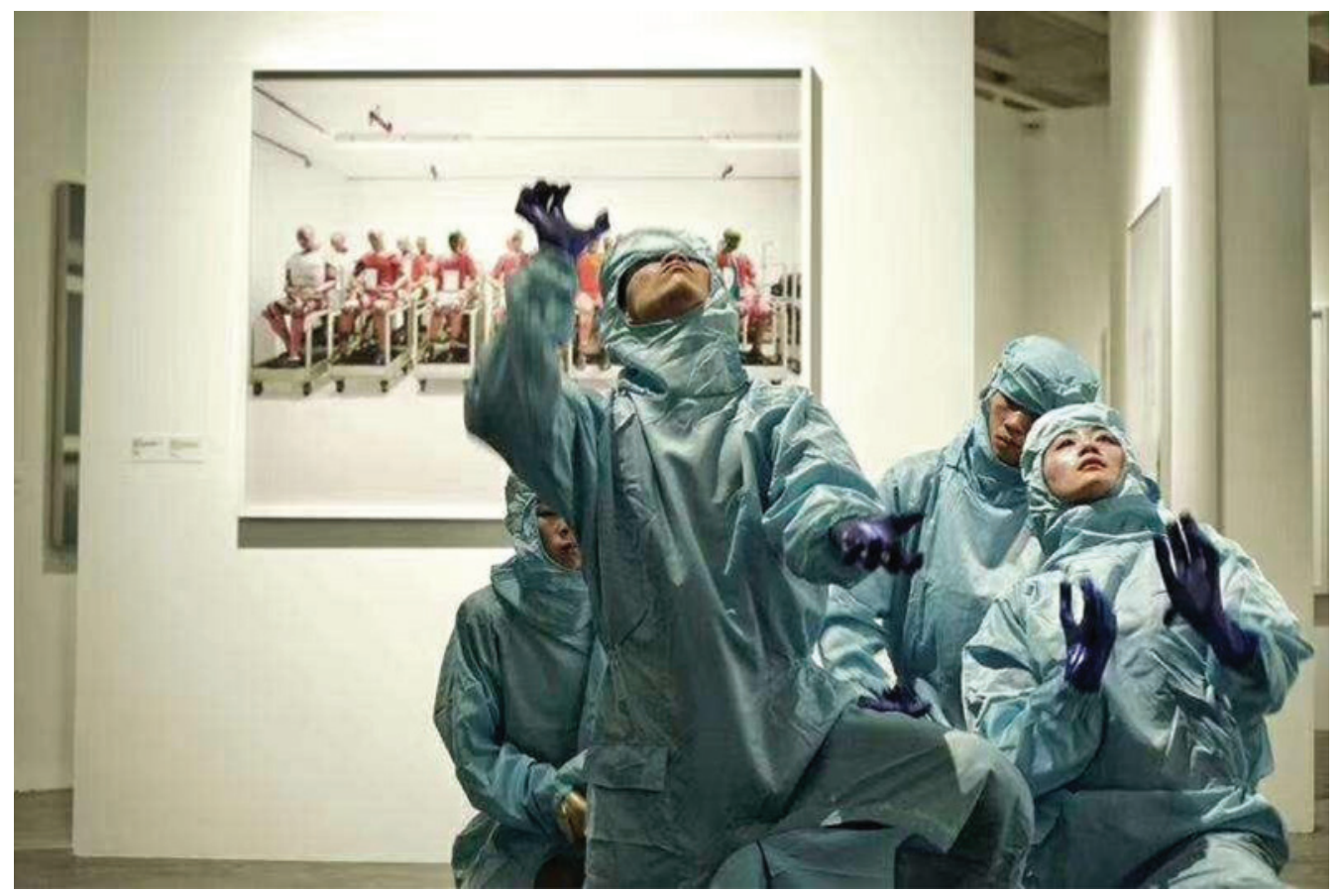

FIGURE 2 | Immanent Fall.

My thinking, judgement and deep concern about life have always contributed to my own understanding of the artistic creation and foresight of certain things. "Immanent Fall" which was completed in 2019, was only a hint, hypothesis and imagination of 
the existence of danger, but what happed later in reality was exactly so similar and so tragic. This work was constructed under the grand theme of the photography exhibition "Civilization: The Way We Live Now" series (UCCA, 2019) presented in the UCCA Center for Contemporary Art in Beijing, that urged me to think about the concept of civilization and the way human beings interpret civilization. This exhibition consisted of more than 250 works by more than 120 photographic artists from Asia, Australia, Europe, Africa and the Americas, each work represented an era, and showed the historical and cultural changes that people have experienced from the Industrial Revolution to the Contemporary Era.

In the process of development, human beings have experienced many disasters. For example, smog in London during the Industrial Revolution, and the current industrial water pollution, air pollution, land pollution and so on. Industrial revolution has brought an era of economic prosperity to human beings, but meanwhile it has also brought a series of problems where people are suffering from a variety of bitter consequences. From the last picture of the exhibition "Civilization: The Way We Live Now" series, I saw the advent of hi-tech and artificial intelligence, and from this came the inspiration and question: When the age of robots began to emerge, what challenges did you think were in store for human beings? This was my awareness and thinking based on the current era. Suddenly, based on this inspiration, I chose to put biohazard suits on my dancers, which was so unexpected and inadvertent coming from a momentary perception. Because of the biological nature of modern technology, future wars are more likely to be biological wars, such as virus wars, where people must wear protective clothing to guard themselves. Protective clothing was just a conceptual existence, and it seemed that only with such things can human beings be protected. This conceptual clothing reflected the current state human beings are living in, and it may also be used as antivirus, also anti-bacteria or anti-pollution clothing... In the work of "Immanent Fall" (Hou Ying Dance Theater, 2019), protective clothing was just an alternative symbol. In the end, the work was aimed at making people think, can humans save the earth, or the earth save humans; whether human beings will destroy the world, or the world will destroy humans? In this process, human beings can be very strong but very fragile and small at the same time; the earth can instantly make humans disappear, while humans can also make the earth become extinct.

\section{Life is so humble.}

Finally, it will turn into dust and return to the earth.

Aimee: In the last part of "Immanent Fall", when the dancers lead the audience through the exhibition hall, they have fully integrated into their inner world. And at the same time, the interaction between the dancers and the audience also promoted their integration as a whole. Because of this interaction, everything was different. What kind of state was that?

Hou Ying: As in the final pose of the work, all the dancers walked to the front of the audience (see Figure 3), their gestures were like pliers-shaped spanners, opening and 
passing through the eyes of the audience to the back of their head. The dancers tried to unload and reassemble the human as a machine without touching their body, only using minds to assume and perform the above movement, splitting human's arms and legs and breaking the human body apart like a machine with the trigger, this was just a concept of preview. When the audience saw the actor stepping towards them and doing these actions, they all showed a state of panic, as every action seemed to hit the audience's body, even if the actor didn't touch them at all. This was exactly my inner language for this creation. Up to now, human beings have been in a state of panic because of COVID-19, like the final part of the work, all the actors with chemical protective clothing began to slowly fall to the ground, crawled and moved in a state of lowliness and downturn. Man returned to the land, to the deep underground, turned into dust and finally back to earth. It seemed that there was a sense of world destruction, all the things were beaten, human beings became dust merging with the earth and disappeared quietly. Life is so humble. Finally, it will turn into dust and return to the earth.

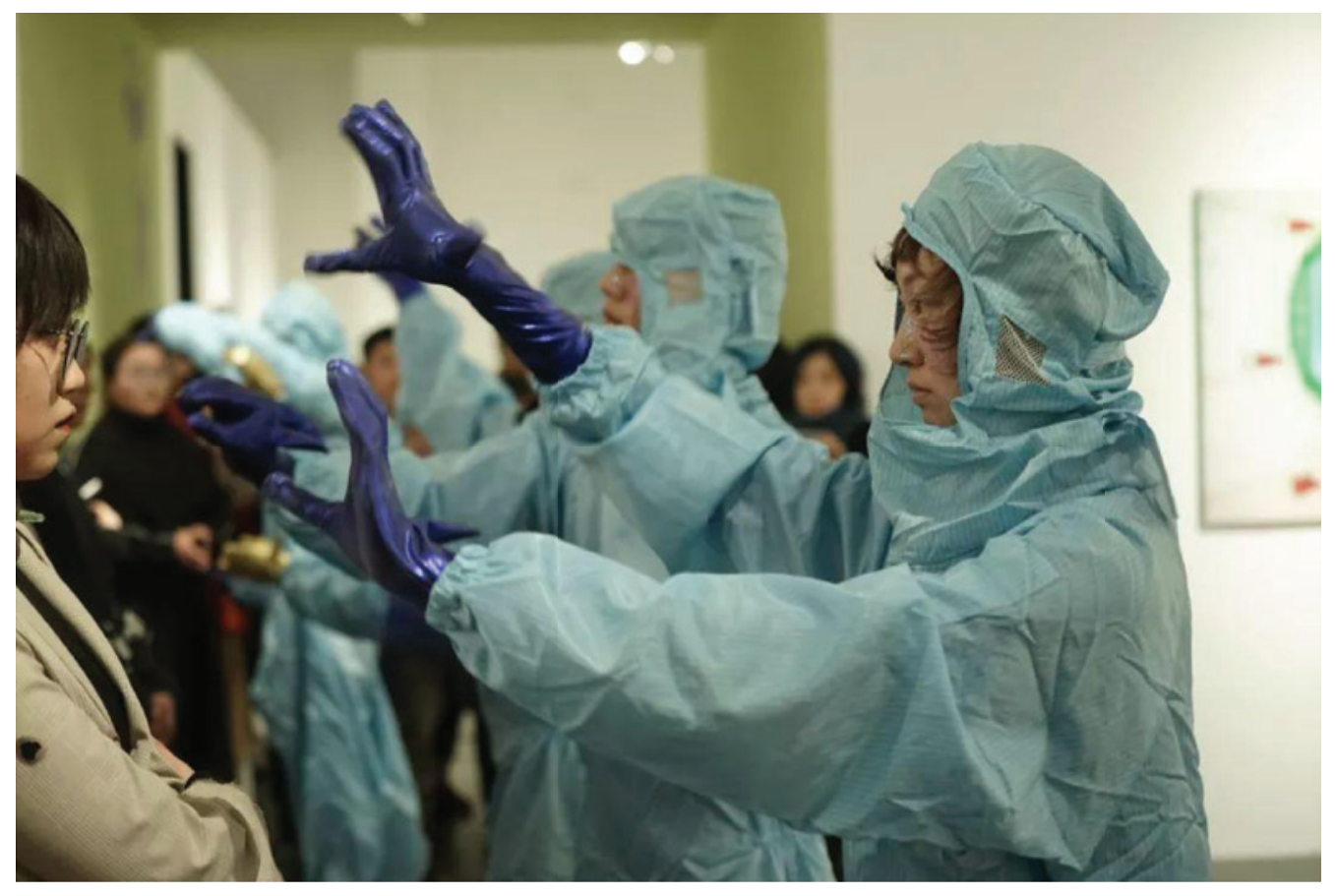

FIGURE 3 | Immanent Fall.

The audience said that there was a sense of inexplicable sadness after watching the dance, but what I wanted to express was not the sadness of life, but the law that human beings would eventually turn into dust and go back to the earth, what a humble life. Everything would go back to their original point in the cycle based on the laws of nature, and civilization was also the same being constantly updated, subverted and destroyed. For thousands of years, in such alternation, human beings have been 
constantly changing, renewing and reproducing, and thus a state of human prosperity has emerged. So, can human beings learn some lessons? Let this destructive cycle come later, be less, and let this highly civilized era last a little longer. Do you want to destroy yourself so quickly? These are the things that human beings may have to think about.

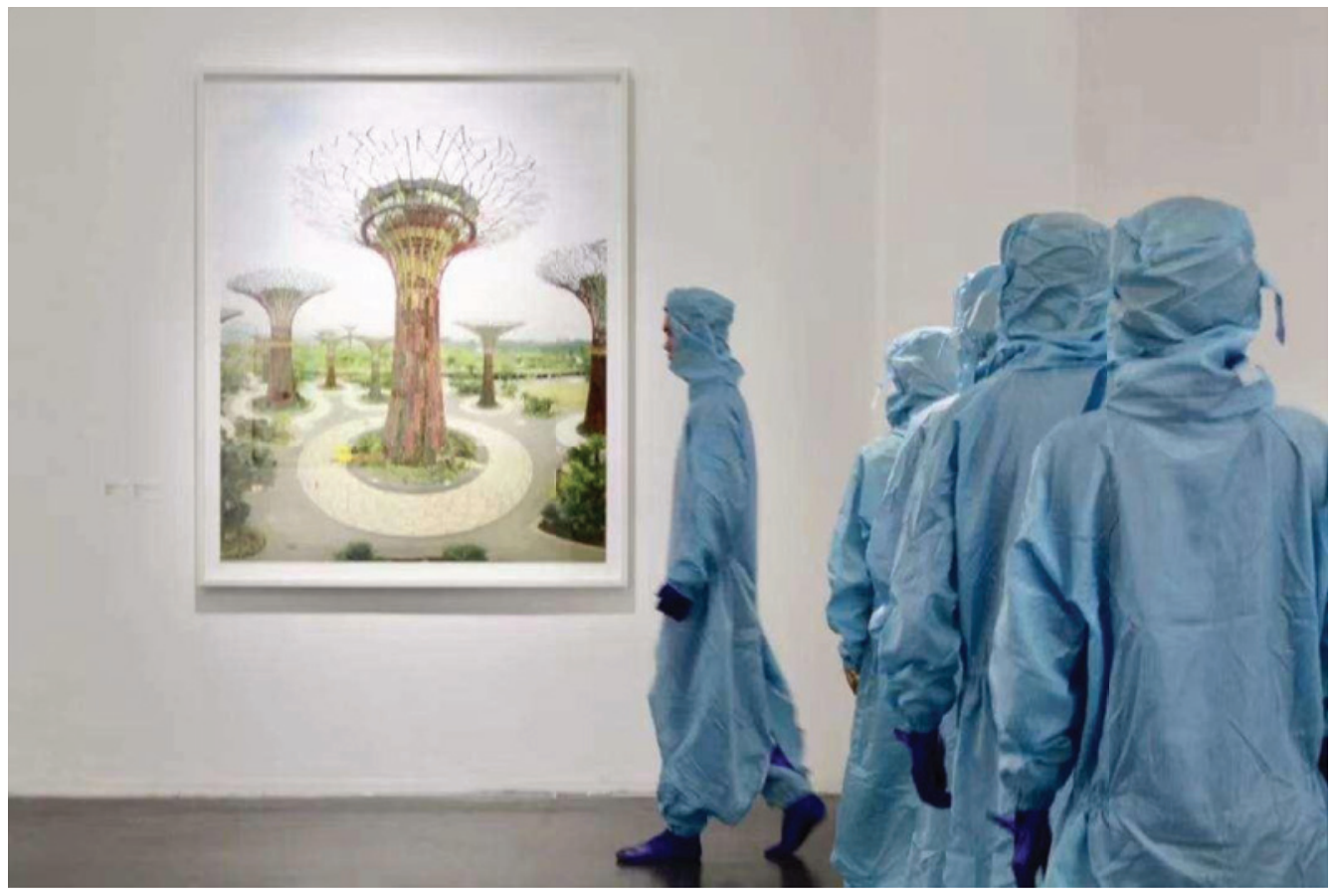

FIGURE 4 | Immanent Fall.

"Hou Ying's modern dance "Immanent Fall” is not only a dialogue with civilization, but civilization itself (see Figure 4). It communicated with hundreds of human photos in the exhibition hall, making the scene have a wonderful effect of independence and a mutual view, and let the viewer see that there seems to be a hissing, electric and soul communication between them. It allows people to sink in the calmest but most charming and shocking part of arts and human nature. At the same time, this is a dance that can only be performed in the exhibition hall, so it is extremely extravagant. It is like time, flowing around, breaking through the body, and any bit of harvest or regret are instantaneous that cannot be turned back and cannot be retained." by Zhang Chang, a commentator (Hou Ying Dance Theater, 2019).

3. An artistic work must enlighten people, awaken people, grasp people's attention, stimulate people's thinking and resonate with people.

Aimee: Although I have known you for more than ten years, in the past two years, you have made me feel very differently. You are constantly creating new dance works that 
have made you not only a dancer, but more like a thinker and an artist. In your opinion, what is art? And when human beings encounter natural disasters such as epidemics, what kind of enlightenment can artists bring to human beings?

Hou Ying: Actually, I have seen my work in the past years to be more about dance, not involving art. However, in the last two years, I have felt deeply about art, and have tried to figure out what art really means. The perspective and mode of thinking as artist was completely different as a choreographer. As a choreographer, I think more about the structure, music and clothing, and the flow which make it a complete song and dance drama; but as a contemporary artist, I think more from the perspective of contemporary art, which is piecemeal and with the perception and awareness of the current state of human existence. I believe that the presentation and appearance of an artistic work must enlighten people, awaken people, grasp people's attention, stimulate people's thinking arouse sympathy among people.

Through the expression of art, people can be deeply aware of the problems existing in current living conditions. This kind of visual art can strengthen human vigilance to upcoming disasters, instead of people following the crowd in a state of numbness. It is the state of numbness that is the biggest crisis for mankind, which will eventually bring great harm to ourselves.

Before creating, I read a lot of books. Albert Camus' "The Stranger" and "The Plague" shocked me very much. Literary works by prophets like Camus are treasures for mankind. As contemporary artists, we are required to make a contribution to human beings and society, as the artist should be the antenna of the human beings. Through the means of art, they draw the attention of human beings and society to the problems that exist at present. Artists use art as a magnifying glass to enlarge a very small thing to form a kind of visual art, which brings a sense of impact to human beings. Just like my work "Winter Solstice" (see Figure 5), when I showed it to people at the New York Art Foundation and Art Gallery, they were deeply impressed by the suffocating damage and impact of haze on us and the extent to which it has damaged our lives, which was suffocating. The expression and expansion of art, which lets people have a deep empathy and a strong sense of impact, makes people awaken and reflect.

There are arts that aims to discuss, present, express and stimulate hormones. But for me, art will never be a stimulation of hormones. "Immanent Fall" was more like a dialogue with myself, an observation and awareness of the entanglement and confusion both in the dimension of the internal and external. Just like human civilization, when human beings are deeply hurt, then they are urged to awaken. My work in last year was finished under the "Civilization: The Way We Live Now" series with a reflection on the development of the intelligence era after the Industrial Revolution. There were presuppositions and concern about human beings in my work, but they were not as violent and shocking as the actual pain. As even the greatest art can never describe authentic pain. What is happening now urges us to stop and think about what kind of role human beings are playing in the process of civilization. What is civilization, human nature and conflict...? Artists can always learn, grow, find themselves and talk with the world through art. 


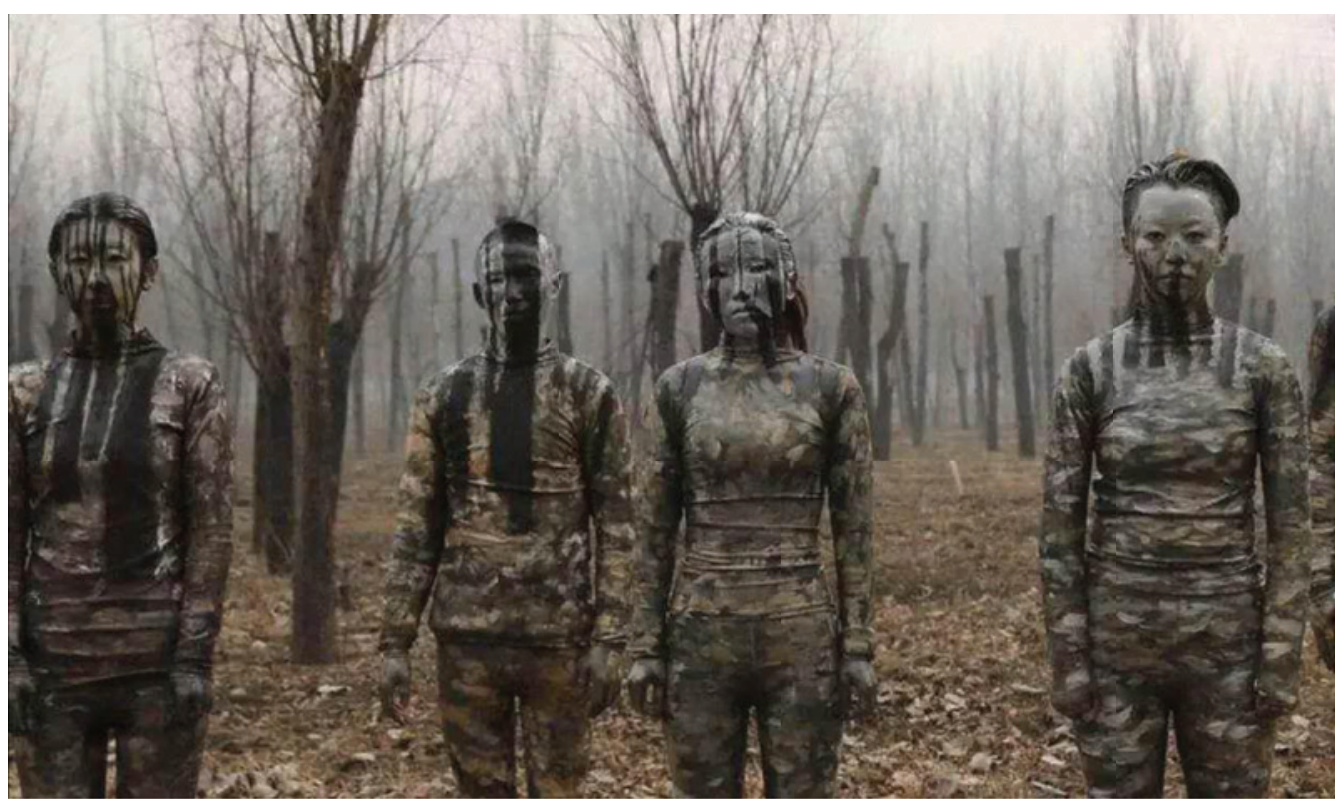

FIGURE 5 | Winter Solstice.

\section{4. "'Survival and Awakening'}

The theme that artists are always keep vigilant and attention to."

Aimee: You put forward at the New York Arts Center that "Survival and Awakening" was a theme that artists always remained vigilant of and paid attention to. From your work the "Winter Solstice" (Hou Ying Dance Theater, 2016) in 2016 with dancers invisible in the outdoor environment, and the work "Immanent Fall" in 2019 with dancers walking through the indoor environment, I have seen your thinking about human survival, your exploration of the relationship between human bodies, space, the environment and the state of living. You have started from the human body, expressed the subconscious reaction of human beings through dance, and reflected on the helplessness and fear of modern people.

Hou Ying: Over the decades, it seemed that our dance art preferred to present beautiful things or only the dance pattern to the audience. However, over the years in China, I have gained a deeper understanding of Chinese society, its people and their lives. Their suffering, sadness, despair and anxiety have contributed to my philosophical thinking about the living environment of human beings, that is, under what kind of living environments would human beings be urged to express themselves better? As this natural disaster comes upon us, I have seen the fragility, helplessness and struggle of us humans.

In terms of my personal creation, there is no eulogizing or sugarcoated language. In the context of contemporary dance or art, my works are usually of thought, disclosure, warning, and even being critical, which pushes people to explore, think and act. 
The development of civilization has far exceeded the evolution of humans, and human beings, as an organism, must strive to adapt to such evolution. From the ancient boundaries of civilizations to modern life, dominated by information and money worldwide, a global civilization and collective psychology have affected human convergence such that people share the same desire, information, products, as well as anxieties and fantasies. Escape is no longer meaningful.

Under this premise, the "Winter Solstice" (see Figure 6) was born. A few years ago, the haze in Winter Solstice was a great crisis for mankind, and we were very helpless in that crisis. For me, this kind of artistic expression was simple and real, but very powerful and meaningful. Such works of art expressed the real problems people were facing, expressed the real living state of people in that era, and expressed the authentic heart of people in that state.

Artists are required to think about what art can do when a disaster comes? What's the meaning of art? Art is the work that need to be done before the disaster coming, aiming for awakening human and calling for love and peace. In a society that is full of freedom, equality, love and justice, disasters will be avoided and reduced. As you take care of the landscape and the earth, in turn, the landscape and the earth will also care for human beings. The existence of art is a single-plank bridge that helps human beings to avoid disasters and complete their lives.

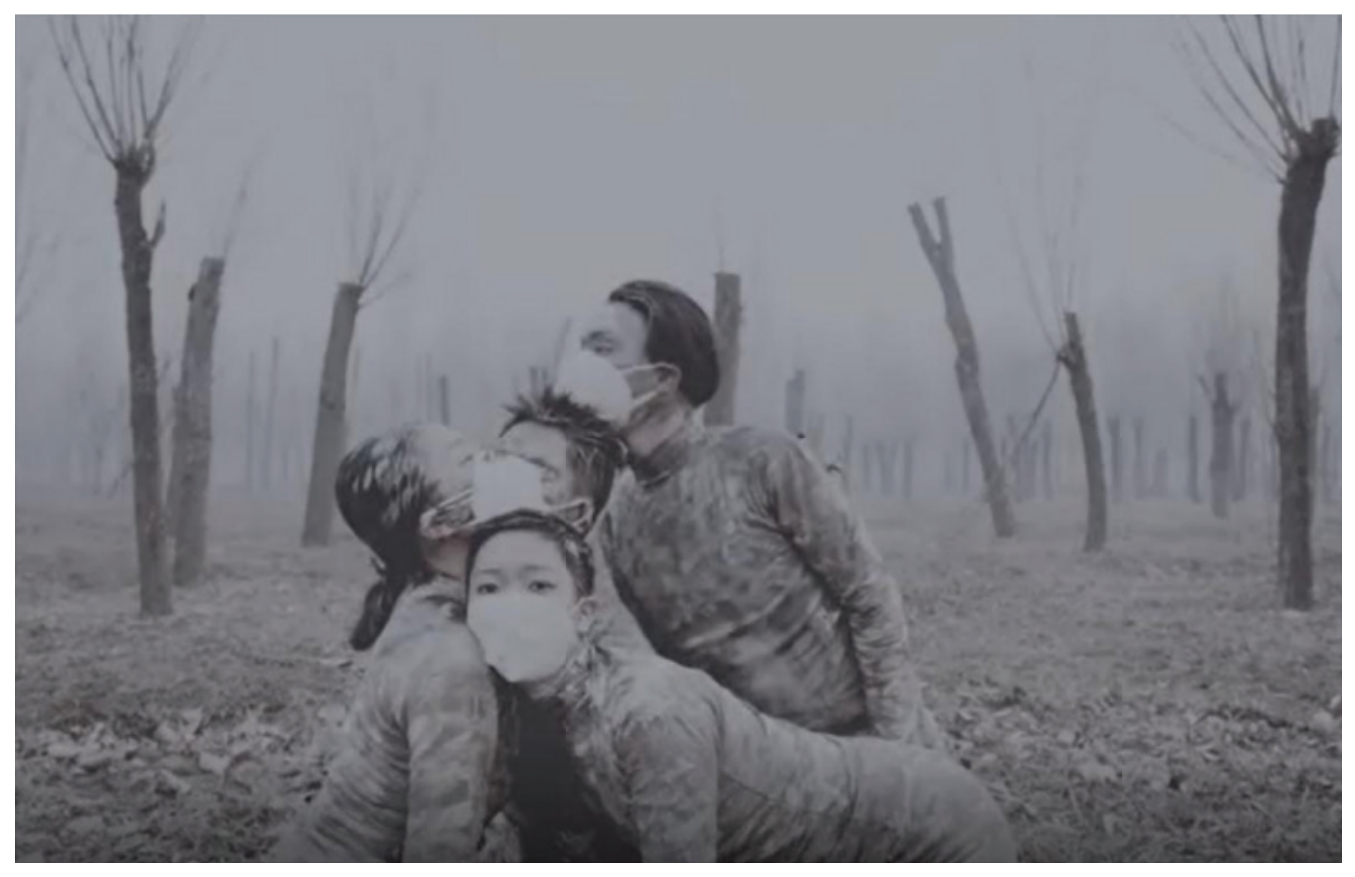

FIGURE 6 | Winter Solstice.

I have been well advised for many years that to protect the life of art, is not say it but just do it. But what they never know is that no freedom of thought, no existence of art. Thoughtless art is meaningless. Today, we use life in exchange for awakening of freedom. 


\section{The community of life was just integrated as one.}

Aimee: As the number of confirmed patients in Wuhan surged, patients were admitted to the mobile cabin hospital, and the whole city was filled with anxiety, helplessness, fear and unease. However, in the past two days, the dancing by patients and nurses in hospital has spread over the Internet, really surprising and amazing people. We saw fresh lives in bloom. The cheerful dance steps conveyed not only their positive and optimistic attitudes, but also their confidence to defeat the epidemic. What's your opinion?

Hou Ying: I believe dance itself has the function of healing. Although I'm now in New York on the other side of the ocean, I felt like I was in Wuhan, I felt like I had lost countless family members, my parents, my husband, and my brothers and sisters ... I believe this emotion to be a kind of empathy and resonance on the same frequency that although right now I am so far away from Wuhan, but every nerve in me seems to really feel their pain. Earlier this year, I returned to New York, I was very sad and sorrowful when I saw the news of the COVID-19 outbreak in Wuhan that one day when I was eating in a restaurant, I suddenly began to cry. The people there came over and looked at me, not knowing what had happened to me... I had nothing to hide at that moment, sadness is an authentic emotion, as countless and innocent lives have been taken away, leaving their families behind. You see I had some physical reaction, even though I was in New York, even if they were not my family members, the shock and pain caused by the disaster were beyond words. This may exactly be the so-called human community: that others were you, you were others, the community of life was just integrated as one (see Figure 7).

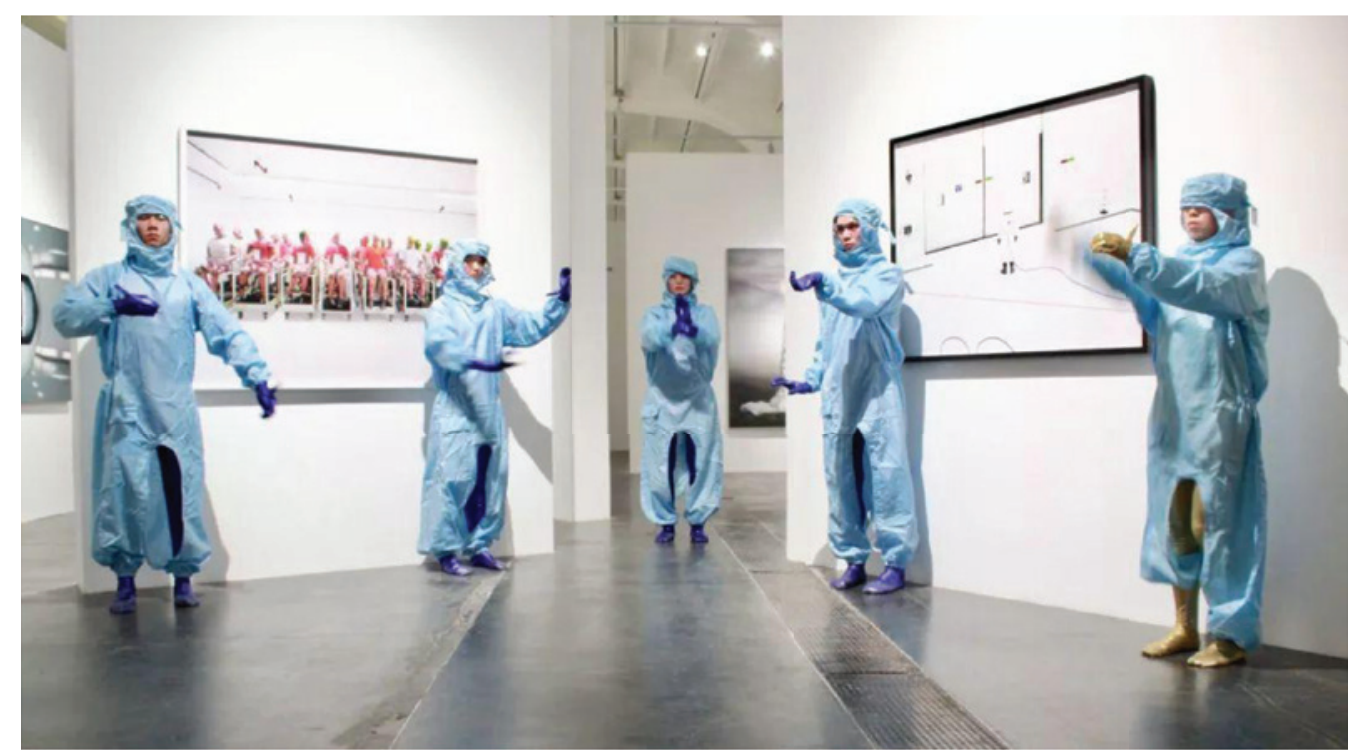

FIGURE 7 | Immanent Fall. 
So, when I saw the doctors and patients dancing together in mobile cabin hospital, I felt relaxed. In fact, during this period, I did not want to talk about art, to do art, nor to make any dance videos, as I had no desire or need to dance to express my sadness. Nothing can express my sadness and condolences of people who have lost their loved ones, so I have refused all my dance invitations, as at that moment, I thought it to be disrespectful to the dead.

As an artist, I have to say that presenting this special moment in dance or art form is meaningless for me, and instead, we have to put down all the sing and dance, letting the sadness flow out quietly. I have stopped all art-related activities, so I will not express my condolences for this disaster in any artistic way. But I was so happy to see people dancing in the mobile cabin hospital and to witness the strong survival ability and indomitable vitality of the great Chinese people.

\section{About the Authors}

Aimee T. Liu 刘婷, was previously a lecturer of the Psychological Counseling Center at Beijing Contemporary Music Academy, China. She is currently the secretary for the Chinese Group of Arts Therapy, the Chinese Psychological Society, and is also an acquisition's editor of Creative Arts in Education and Therapy (CAET). E-mail: aimee_liut@hotmail.com

Hou Ying 侯莹, is a founder of Hou Ying Dance Theater. She is also a distinguished modern dancer and choreographer with a global reputation. The art critic of the Beijing News described her as "the Kafka of dance”. E-mail: houying@houyingdance.com

Amanda Liu 刘丝雨, is a freelance editor and translator in Wuhan Yi Ye Psychological Services Center. She is also a journalist mainly focused on business and economics. E-mail: amandadaiyu@163.com

\section{References}

Hou Ying Dance Theater (2016). Winter Solstice. http://www.houyingdance.com/new-gallery-2

Hou Ying Dance Theater (2019). HYDT x UCCA Immanent Fall. https://mp.weixin.qq.com/s/ TXOB5hsxTtEVZ4ODgXTnLg

Hou Ying Dance Theater (2019). Immanent Fall. http://www.houyingdance.com/new-gallery-1

UCCA (2019). “Civilization: The Way We Live Now” Series. https://ucca.org.cn/en/exhibition/civilizationway-live-now/

UCCA Beijing (2019). “Civilization: The Way We Live Now”. Series Immanent Fall. https://mp.weixin. qq.com/s/XBZzj6SRf9BPMsPw64v_NQ 